\title{
The High Cost of Transferring the Dream
}

Kim Brooks*

\begin{abstract}
Cases might be valuable for more than the legal lessons they offer. This paper argues that cases present an archive of evidence that can help us reason backward to better understand the fissures in the ways humans interact and how our social, political, and economic systems generate tensions in their lives. More specifically, the paper looks through a small window into the lives of the people who find themselves caught between our collective and individual expenditure aspirations. It explores the circumstances in which individuals find that their outstanding tax debts pose a threat to their ability to maintain ownership of their home.
\end{abstract}

Keywords: tax policy, lived realities, financial distress, legal facts, home ownership

\section{Résumé}

Les affaires judiciaires peuvent être intéressantes à plusieurs égards au-delà de leur utilité comme enseignements à tirer. Lauteur soutient que les affaires judiciaires présentent une véritable archive de preuves nous permettant de raisonner en amont afin de mieux comprendre les fissures dans les interactions humaines et comment notre système social, politique et économique est cause de tension dans la vie des gens. Plus précisément, l'article donne un coup d'œil sur la vie des gens qui se trouvent coincés entre nos aspirations de dépense collectives et individuelles. Il examine les circonstances dans lesquelles les personnes constatent que leurs dettes fiscales menacent leur capacité à demeurer propriétaires de leur résidence.

Mots clés : politique fiscale, réalités vécues, difficultés financières, faits juridiques, propriété immobilière

\footnotetext{
* The author would like to thank Neil Barass, Mary Brown, and Kacie Oliver for their research assistance and editorial care and Constance Backhouse, Benjamin Berger, Suzanne Bouclin, Denise Reaume and participants in the "Law and Politics" workshop at USC Gould School of Law, the Critical Analysis of Law workshop at the University of Toronto, and the faculty seminar series at the Schulich School of Law at Dalhousie University. Thanks are also extended to the Social Sciences and Humanities Research Council of Canada for their support and to three anonymous reviewers who provided detailed and helpful comments.
}

Canadian Journal of Law and Society / Revue Canadienne Droit et Société, 2016, Volume 31, no. 3, pp. 317-333. doi:10.1017/cls.2016.10 


\section{Living the Canadian Dream}

Katherine Bourget and her husband, Ed Oosterman, likely dreamed of building their own home. Something big enough for themselves, with a place for Ed's mother, Jansje, to live, too. The financial pressures of translating the dream into reality must have been significant. Ed's trucking business was in trouble. Still, they found a piece of vacant property near Woodstock, Ontario, that was within financial reach. In planning the construction, they imagined a suite in a separate building for Jansje. As the project evolved, they decided that a breezeway would be built to attach the suite to the main house. It's possible that the family turned their mind to how cold it can be in the winter and to the stresses of shovelling walkways as we age. The home was built as planned and Jansje paid for the costs of constructing her space in the home. The trucking business declined. Ed accrued a tax liability of $\$ 68,252$. The trucking business failed. To creditor-proof the house, Ed transferred his half-interest in it to Katherine. ${ }^{1}$

When Ed transferred his property to Katherine, he brought her into his tax woes. The Income Tax Act contains a rule that prevents a tax debtor from avoiding his or her tax debt by transferring property (including money) to a related person. ${ }^{2}$ The purpose of the rule is to prevent a taxpayer from avoiding his or her tax liability by transferring property to a spouse, minor, or other non-arm's length person without receiving proper consideration in return. The rule operates in a straightforward way: if a tax debtor transfers property to a non-arm's length person, ${ }^{3}$ directly or indirectly, at a time when the tax debtor is liable to pay tax (even if not yet assessed), the recipient of the property becomes liable (jointly and severally with the tax debtor) for the outstanding tax debt (and interest on the debt) up to the value of the transferred property. If the recipient of the property paid some amount in exchange for the property, the liability is reduced by that amount. ${ }^{4}$ When the rule applies, the Canada Revenue Agency can seize any of the assets of the transferee to satisfy the tax debtor's debt (not just the property transferred). There is no limitation period on the liability. It does not matter whether the transferee knew about the tax debt, and the tax debtor does not need to have had an intention to attempt to defeat payment of the tax debt.

The rule applies to all kinds of transfers-from contributions to a spousal RRSP, ${ }^{5}$ to school and summer camp fees for children, ${ }^{6}$ to wedding gifts, ${ }^{7}$ to

This vignette is based on Bourget $v$ R, 2008 TCC 634, [2009] 3 CTC 2286 [Bourget].

See Income Tax Act, RSC 1985, c 1 (5th Supp), s 160.

The transferee must be (1) a spouse, common-law partner, or a person who has since become a spouse or common-law partner; (2) a person under eighteen years of age at the time of the transfer; or (3) a person with whom the transferor was not dealing at arm's length. (Dealing at arm's length is defined in section 251 of the Income Tax Act, ibid. For individuals, related persons, including individuals connected by blood relationship, marriage, common-law partnership, or adoption are deemed to be not dealing at arm's length.)

4 In some cases, the court accepted that payments between spouses arguably required by family law statutes might be considered as part of the remuneration received for the transfer; however, more recent decisions, and especially Yates $v$ R, 2009 FCA 50, [2009] 3 CTC 183, reveal that transfers for payment of family household expenses and transfers for payment of legal obligations to family will not be included in the calculation of consideration received for the transfer.

Wannan $v$ R, 2003 FCA 423, [2004] 1 CTC 326.

Goldberg $v$ R, 2003 DTC 190, [2003] 2 CTC 2592 (TCC).

Gitelman v R, 2007 TCC 544, [2008] 1 CTC 2479. 
endorsing a cheque. ${ }^{8}$ It applies to subsequent recipients of the property-so, for example, the section applies where the tax debtor transfers property to a nonarm's length recipient and that person transfers it on to someone else. ${ }^{9}$ If, however, the property is transferred as part of a formal separation arrangement between former spouses, the provision does not apply. ${ }^{10}$ That carve out is designed to ensure that spouses in the process of separation are able to allocate property between themselves without the potential for an undisclosed tax liability to attach to the transferee. There have been almost 1,000 reported cases on section 160 since its introduction in 1951. ${ }^{11}$

Like Ed and Katherine, all individuals have a list of personal consumption aspirations that demand the use of their scarce financial resources. We spend money on food, shelter, clothing, educational opportunities, transportation, and services. Unique among individual financial decisions, home ownership rests at the pinnacle of individual consumption. Newspapers are filled with stories celebrating the joys and benefits of homeownership. It is described as the "Canadian dream." ${ }^{12}$ Experts sometimes recommend purchasing a home, even if the economics do not make sense, because we feel better when we own a home or because home ownership forces savings. ${ }^{13}$ Our tax system encourages home ownership. ${ }^{14}$ And despite the contrary warnings to consumers of the risks of homeownership ${ }^{15}$

$8 \quad$ Banks $v$ Canada, 2011 TCC 415, 2011 DTC 1318.

9 See e.g. Jurack $v$ R, 2003 FCA 58, [2003] 2 CTC 165 and see new rule section 160(1)(e)(ii) (added in 2012, retroactive to December 21,2002).

10 See subsection $160(4)$.

11 The section has received a reasonable amount of attention from tax practitioners, generally in the form of case comments, but almost no attention from tax academics. See e.g. Cy Fien, "Directors' Liability and Indemnifications, Section 160 Assessments, and Ordinary Course of Business Provisions," Canadian Tax Foundation 53:1 (1992); Ed Kroft and Deborah Toaze, "Section 160 of the Income Tax Act-Transferee Liability," Blakes on Canadian Tax Controversy \& Tax Litigation (June 2014); David Nathanson, "The Fairness Package, the Long Reach of Section 160, and Solicitor-Client Privilege," Canadian Tax Foundation 49:1 (1991); Ray Rubin, "The Long Arm of Section 160: Montreuil et al. v. The Queen," Canadian Tax Journal 43(2) (1995): 420; Bruce Russell, "Addison \& Leyen: Judicial Review of Section 160 Assessment Decisions," Tax Hyperion 3(5) (2006); Bruce Russell, "Gambino: Section 160 Assessment Soundly Vacated," Tax Hyperion 5(12) (2008); Bruce Russell, "Yates: Are Inter-Spousal Transfers for Household Expenses Section 160 Exempt?" Tax Hyperion 6(4) (2009); Elaine Sibson, "Revenue Canada’s Long Collection Arm: Jeopardy Orders, Section 160 Assessments, and Directors' Liability, Canadian Tax Foundation 26:1 (1998); Karen Stilwell, “Crischuk: Section 160 Family Law Considerations," 7(6) Tax Hyperion 7(6) (2010); Manon Thivierge, "Emerging Income Tax Issues: Substance over Form Revisited, Section 160 of the Income Tax Act, and Series of Transactions," Canadian Tax Foundation 4:1 (1993).

12 Alison Smith, "Rethinking the home ownership dream," CBC News Business, January 31, 2014. Accessed at http://www.cbc.ca/news/business/rethinking-the-home-ownership-dream-1.2519201 3 January 2016; Jennifer Paterson, "Canadian Home Ownership Gets More Unaffordable" Canadian Real Estate Wealth, April 3, 2015. Accessed at http://www.canadianrealestatemagazine.ca/ news/canadian-homeownership-gets-more-unaffordable-189967.aspx 3 January 2016.

13 Noreen Rasbach, "Saying no to the home-ownership dream," The Globe and Mail, October 20, 2010. Accessed at http://www.theglobeandmail.com/globe-investor/personal-finance/home-cents/ saying-no-to-the-home-ownership-dream/article1381048/ 3 January 2016,

14 See e.g. the principal residence exemption defined in section 54 of the Income Tax Act, RSC 1985, c 1 (5th Supp).

15 Rob Carrick, "Why Canada's cult of home ownership is in trouble," The Globe and Mail, January 20, 2014. Accessed at http://www.theglobeandmail.com/globe-investor/personal-finance/householdfinances/why-canadas-cult-of-home-ownership-is-in-trouble/article16419965/ 3 January 2016; Robert J Shiller, “Owning a Home Isn't Always a Virtue," The New York Times, July 13, 2013. Accessed at http://www.nytimes.com/2013/07/14/business/owning-a-home-isnt-always-a-virtue. html 3 January 2016. 
and tales of home price bubbles, ${ }^{16}$ more people own homes in Canada than ever before. $^{17}$

We also have collective dreams. Oliver Wendell Holmes, Jr., reportedly and famously claimed, "[t]axes are the price we pay for a civilized society." 18 If our collective aspirations include streetlights, playgrounds, libraries, schools, and hospitals, among other public goods, then we must pay for those goods collectively. Taxes serve as the instrument that allows us to do so. To that end, the price of our taxes reflects the price of those public goods. As individuals, we need to balance the cost of our public consumption (reflected by the cost of our taxes) with the cost of our private consumption.

At its core, all of tax politics is about finding the appropriate balance between our collective aspirations and our individual wants and needs. This paper looks through a small window into the lives of the people who find themselves caught between our collective and their individual expenditure aspirations. More specifically, it explores the circumstances in which individuals, like Katherine and Ed, find that their outstanding tax debts pose a threat to their ability to maintain ownership of their home.

\section{The Value of Looking at the Mirror's Mirror}

This paper is part of a larger project where I use the facts in tax decisions to reveal something about who we are. ${ }^{19}$ To provide some of the detail of the lives lived where our dreams of the collective provision of goods collide with our dreams of individual homeownership, this paper studies the section 160 tax cases where the taxpayer (often referred to in this paper as the transferee) received a transfer of an interest in the family home from a related person when that related person had an outstanding tax liability. As noted, the consequence of the transfer is that the transferee becomes liable for the outstanding tax

16 In August 2014, The Economist warned that house prices in Canada were more than 25\% overvalued: J.M.F. and D.H., "Location, location, location: Our interactive guide to the world's housing markets," The Economist, August 29, 2014, updated October 7, 2015. Accessed at http://www. economist.com/blogs/dailychart/2011/11/global-house-prices 3 January 2016.

17 Between 1971 and 1991 home ownership rates in Canada were between 62 and 63 percent; however, by late 2008 the homeownership rate reached a historic high of 68.8 percent. Steve Pomeroy, "Against all odds: home ownership rising among young buyers," Focus Consulting Inc, November 2013. Accessed at http://www.focus-consult.com/wp-content/uploads/2013/11/ Refuting-expectations-Blog-Nov-23.pdf 3 January 2016.

18 There are variations on this story. President Roosevelt quoted Oliver Wendell Holmes, Jr. in a speech to Congress about tax evasion in 1937, stating, "Mr. Justice Holmes said 'Taxes are what we pay for civilized society.' Too many individuals, however, want the civilization at a discount." In Franklin D. Roosevelt, "President Urges Legislation to Prevent Tax Evasion. June 1, 1937" The Public Papers and Addresses of Franklin D. Roosevelt, 1937 Volume, (New York: The MacMillan Company, 1941), 238 (HeinOnline). In 1961, in a book about Mr. Justice Holmes, Felix Frankfurter reports, "Mr. Justice Holmes ... did not have a curmudgeon's feelings about his own taxes. A secretary who exclaimed, 'Don't you hate to pay taxes!' was rebuked with the hot response, 'No, young feller. I like to pay taxes. With them I buy civilization."' In Felix Frankfurter, ed., Mr. Justice Holmes and the Supreme Court. 2nd ed. (Cambridge, Massachusetts: The Belknap Press of Harvard University Press, 1961), 71.

19 See Kim Brooks, "Cameos from the margins of conjugality," in After Legal Equality: Family, Sex, Kinship, ed. Robert Leckey (Routledge, 2014), 99. Throughout this paper I deliberately use "we." The point is to underscore that as scholars I do not think we are separated from the subjects of study. 
liability to the extent of the value of the transferred asset for which consideration was not paid. In other words, if the transferor had an outstanding tax liability of $\$ 200,000$ and transferred the family home to his spouse at a time when it was worth $\$ 150,000$ and she did not pay him for the house transfer, she would become liable for her husband's tax liability to the extent of the value of the house: $\$ 150,000$. If, however, she paid him $\$ 20,000$ as consideration for the transfer of the house, she would only become responsible for $\$ 130,000$ of his outstanding tax liability.

To provide another concrete example of the application of section 160, imagine Helen and Albert Goldhawk. Helen was a social worker; her husband, Albert, was a chartered accountant. Albert started an accounting business in partnership. His business partner demanded that Albert enter into a marriage contract with Helen that would stipulate that she would have no right to Albert's partnership interest if the couple separated or divorced. As you might imagine, Helen, who had been married to Albert for well over 30 years at the time without a marriage agreement, was not enthusiastic about the requirement. Nevertheless, she understood that failure to sign the agreement would preclude her husband's business venture. She sought legal advice. Ultimately, she decided to sign the marriage agreement, which would relinquish her right to the partnership interest, in exchange for Albert's share in the matrimonial home. The contract was signed on June 5, 1989. Helen's abandonment of her interest in the business was well recorded, but there was no simultaneous written record of Albert's agreement to transfer Helen his interest in the matrimonial home. Albert worked in the partnership for ten years, but the partnership relationship was a rocky one. In 1999, Helen and Albert took steps to insulate themselves in the event that the business partnership dissolved. It was only then, in October 1999, that Albert formally transferred his share in the matrimonial home to Helen. At the time, the home was worth $\$ 225,000$ and Albert had an outstanding tax liability of $\$ 26,341$. Albert's business partnership came to an end when his partner locked him out of the office in May $2001 .^{20}$

In this paper I use the facts of tax cases, like the facts reflected by the story of Helen and Albert Goldhawk, for two ends. First, I am interested in disrupting legal knowledge hierarchies. We choose cases to read in law school, to explore in case comments and other extended scholarly work, or to cite in advocacy not because of the people that have motivated them, but because of the legal development or doctrine the case represents. But if the purpose of law is to resolve human dilemmas and to help us address pressing public policy issues-which for some might be a contestable claim - then, as important as the legal doctrine is "what happened": the story about why the parties find themselves in front of the court or administrative tribunal. These stories should help us infer something about the kinds of problems real people have and to discern places where our non-legal public policy solutions are lacking. Put another way, the facts of

20 Goldhawk v R, 2014 TCC 132, 6 CTC 2026 [Goldhawk]. The court held that there was insufficient evidence of the oral agreement that the transfer of the half-interest in the matrimonial home occurred in 1989. Therefore, the section 160 assessment was upheld. 
cases might be important in helping us reason backward to where there are fissures in the ways humans interact and how our social, political, and economic systems generate tensions in their lives. ${ }^{21}$

Second, I am interested in whether we could learn something about who we are from the stories that come out of cases; ignore the law altogether. Social scientists have made remarkable discoveries about who we are, employing increasingly thoughtful methodologies. But our scientific projects have limits-ethical, financial, and human. There are sensible ethical constraints on who you can study, what you need to disclose to them in advance, what questions you can ask, and how invasive you can be. Social scientists have limited financial resources-sometimes when an in-person interview would be preferable, a survey tool has to do. There are human resource constraints on how many subjects a researcher can feasibly talk to and how long can be spent with each.

Tax cases provide an unlikely and incomplete archive of the lives lived by those who appear before tax courts. ${ }^{22}$ Unlikely, because few scholars would consider using tax cases as a repository of evidence about how we live our lives. Many people think of tax law as dreary work, characterized more by numbers and receipts than by the texture of human lives. This assumption is wrong in two respects. First, numbers and receipts can present a fascinating story in their own right: who is spending how much on what reveals a good deal about how lives are lived. Second, while the focus of many tax inquiries does not directly entail interrogating the nature of human relationships or the way lives are lived, those facts nevertheless inform every tax decision, even decisions where they hold no obvious relevance for the judicial outcome.

The obvious downside of trying to understand human and public policy dilemmas through cases is that ultimately the judge controls what story gets told, not the researcher, or the people themselves. All social science methods suffer from the effect of the observer problem, and some methods are limited by the bias and selected questioning of the researcher. Similarly, the structure of the court process and the legal distinction drawn between relevant and irrelevant facts has profound and undeniable sorting implications for treating the facts of tax cases as a data set. This project requires tolerating that exploring the facts of tax cases is more like looking at broken pots and trying to draw inferences about how someone uses their kitchen than watching them in the kitchen itself. Or, to try another analogy, the project does not allow us to look in the mirror, it allows us to look in the mirror of us looking in the mirror.

21 There is a scholarship on legal knowledges, but its focus tends to be on the interaction of legal knowledge and its interaction with the knowledges of other disciplines or on the tendency of legal scholars to separate law and the everyday as though they are not mutually constitutive. See e.g. Mariana Valverde, “Which Side Are You On?' Uses of the Everyday in Sociolegal Scholarship," Political and Legal Anthropological Review 26:1 (2003): 86; Mariana Valverde, "Authorizing the Production of Urban Moral Order: Appellate Courts and Their Knowledge Games," Law and Society Review 39:2 (2005): 419.

22 See e.g. Dominique Daniel, "Documenting the Immigrant and Ethnic Experience in American Archives" The American Archivist 73:1 (2010): 82 at 82. (Daniel claims that archivists might, "compile a whole new world of documentary material about the lives, desires and needs of ordinary people.”) 
There have been other projects in tax that have attempted to focus attention on the facts of cases, but the objective of those projects has been different. For example, Foundation Press has released a series of books that tell the "stories" of different areas of law. In 2003, they released a collection edited by Paul Caron entitled, Tax Stories: An In-Depth Look at Ten Leading Federal Income Tax Cases. ${ }^{23}$ But the stories that are being told in that collection are the factual, social, and legal background for the selected cases. The book (or series) does not attempt to shine a light on the facts of the people in the case, and certainly does not attempt to use those facts to learn something about who we are or the ways in which law can reveal gaps in our other public policy responses to human problems. Additionally, that collection, like other pieces that attempt to provide social and economic context to cases or add richness to our understanding of the people behind them, ${ }^{24}$ focuses on what can be learned in one case.

This paper proceeds in two further parts. Part 3 sets out the legal context, describing the evolution of the provision that requires prioritizing our collective aspirations over our private wants in limited circumstances. Part 4 turns to see what can be learned when we look at the people whose lives get caught between their home ownership aspirations and our obligation to pay tax.

\section{The Policy Setting for and the Evolution of Section 160}

This part of the paper recounts how section 160 was developed. Since one of my claims is that isolating and digesting the facts of tax cases helps better understand the human and public policy dilemmas of our times, it seems fruitful to understand the public policy dilemmas drafters and legislators contemplated in the design of the provision.

Over the years there have been a few, relatively modest, changes in the application of section 160 . When it was introduced in 1951, it applied where a person transferred property on or after May 1, 1951, to a spouse or to a person who was under 19 years of age. ${ }^{25}$ In the House of Commons debates at the time of the section's introduction, Parliament was focused primarily on circumstances where the transferor was trying to avoid tax liability on attributed income. ${ }^{26}$ The Minister of Finance, Mr. Abbott, answered a series of questions driving at what happens when a husband transfers an income-producing property to his wife. In those circumstances, the Income Tax Act generally allocates the tax owing on the income produced by the transferred property to the husband for tax purposes. The sense of this rule is to ensure the integrity of the individual taxpaying unit. A husband should not be able to transfer property (without appropriate consideration) to his wife as a means to avoid paying tax on income earned from that property at his tax

23 Paul Caron, Tax Stories: An In-Depth Look at Ten Leading Federal Income Tax Cases (New York: Foundation Press, 2003).

24 See e.g. Debora Threedy, “A Fish Story: Alaska Packers' Association v. Domenico, University of Tasmania Law Review 2 (2000): 185; Rebecca Johnson, Taxing Choices: The Intersection of Class, Gender, Parenthood, and the Law (Vancouver: UBC Press, 2002).

25 An Act to Amend the Income Tax Act, 1947-48, c 52; 1951 c 51, s 17.

26 See House of Commons Debates, 21st Parl, 4th Sess, Vol 5 (13 June 1951) at 4061-4062 (Mr. Abbott). 
rate, which was assumed to be higher than hers. The concern expressed by the Minister of Finance at the time the section was introduced was that, in the absence of (now) section 160, the husband might be able to avoid paying taxes. The challenge was that although the Act operated to ensure he still owed taxes on the income earned by the property, the Revenue Agency would have no ability to seize the property (because it was owned by the wife) if the taxes were not paid. In debates, the Minister clarified that this section would ensure that the wife was jointly liable for the outstanding tax, and that the Revenue Agency would (as a result) be able to seize the property, now owned by her, to satisfy the debt. The scope of the provision, however, even in its earliest form, was much wider than the simple instance of attributed income. Instead, it applied to all tax debts of the transferor that have crystalized at the time of the transfer.

There were no substantial changes in the design of section 160 until 1972. ${ }^{27}$ That year, as part of the broader Income Tax Act reforms, the section was moved to its current location (section 160) and the age for the section to apply to children was reduced from under 19 to under $18 .^{28}$ In 1983 , the provision was widened to add non-arm's length transfers to the list of relationships that attract the application of the provision. ${ }^{29}$

In 1984, the provision was again adjusted, this time to add a carve out for property transferred as part of the separation of spouses. ${ }^{30}$ There was an extended discussion of this change in the Standing Committee on Finance, Trade and Economic Affairs. The tension, of course, is between the legitimate interests of the state in collecting unpaid taxes and the ability of spouses to move forward postdivorce unencumbered by the consequences of their past dealings. The avoidance concern was that eliminating the tax liability on separation would create an incentive for spouses to divorce simply to avoid paying taxes. The exchanges between the Chair of the committee, Mr. Morris (special adviser in the tax policy and legislative branch of the Department of Finance), and Mr. Blenkarn, Mr. Kempling, and Mr. Bloomfield, members of the committee, reveal the human texture of those tensions. The men worked through the possibility that the new provision, which would exempt separation transfers from the ambit of section 160, would result in less tax being collected by the government, the unfortunate consequences for women post-separation in the absence of this rule, and the potential that spouses would divorce simply to avoid the application of section $160 .^{31}$

27 The section number changed from section 49A to section 53 in the statute consolidation in 1952 (Income Tax Act, RS 1952, c 148, s 53). The number of the section was changed (from 53 to 59) and the drafting of the section was cleaned up in the 1970 revised statutes to ensure that the conjunctive "and" and not the disjunctive "or" was employed in 59(1)(d) (i.e. (d) the transferee and transferor are jointly and severally liable to pay the lesser of (i) any amount that the transferor was liable to pay under this Act on the day of the transfer, and [replacing or] (ii) a part of any amount that the transferor was so liable to pay equal to the value of the property so transferred;"). Income Tax Act, RS 1970 , c 148, s 59, enacted in 1972 by $1970-71-72$, c 63, s 160 . The section refers to other sections in the Act. As the Act has been amended over time, those cross-references have been updated.

Income Tax Act, as amended by 1970-71-72, c 63, s 160(1)(b).

Income Tax Act, as amended by 1980-81-82, c 140, s 107.

Income Tax Act, as amended by 1984, c 45, s 65.

See House of Commons, Minutes of Proceedings and Evidence of the Standing Committee on Finance, Trade and Economic Affairs, 32nd Parl, 2nd Sess, Issue No 19 (22 May 1984) at 19:20-21. 
The Chairman: So I transfer all my assets, free of liabilities, to my spouse. It means that the government has nothing it can go against.

Mr. Morris: If you transfer all your assets, yes.

The Chairman: Okay.

The Chairman: That would be a fraud of some sort, would it not? I am talking about a genuine case, where you just walk away from it.

Mr. Bloomfield: Yes, but there could be collusion among people like that, who would rather do it that way and divide it up later if...

The Chairman: This is a very humane section, because a lot of spouses have been stuck with tax liabilities that they never even contemplated.

Mr. Kempling: That is right.

The Chairman: It is a very humane provision.

Mr. Kempling: It also means they go and sell those assets as soon as they can, so there is nothing to leave. In the case I was citing, the woman kept the house for two or three years and then she decided subsequently to sell it; and when she went to sell it, she found there was a lien against it she did not know about.

The Chairman: Exactly.

Mr. Kempling: If she had sold it immediately after the court separation, it would not have attracted...

The Chairman: I know of the exact same case, where the husband had incredible tax liabilities. The wife got the house, and she had to sell the house to satisfy his tax liabilities. It was a very, very heart-rending situation.

I think you are being very humane here.

Mr. Kempling: It should be.

The Chairman: But it also means dilatory husbands can walk away from tax liabilities. We are giving preference to a spouse over the National Revenue, over the federal "fisc," is what we are doing here.

Various clarifying changes to the section were made through the 1990s and into 2000s. In 1998, Parliament revised subsection 160(2) and (3) to change the word transferee to taxpayer. ${ }^{32}$ In 2000, the Income Tax Act as a whole was amended to replace spouse with spouse or common law partner. ${ }^{33}$ In 2002, the section was amended to clarify that the Minister can charge interest on a section 160 assessment from the date of the assessment. ${ }^{34}$ In 2013 two changes were made. First, the section was amended to add the word "solidarily" to the description of the liability of the transferor and transferee to conform with the French language version of the provision (i.e., jointly and severally (meaning both parties are liable and each

Income Tax Amendments Act, 1987, 46-47 Elizabeth II, section 186.

Modernization of Benefits and Obligations Act, 48-49 Elizabeth II, s 1(z 26).

See subparagraph 160(1)(e)(i). 
is liable independently), or solidarily, liable). ${ }^{35}$ Second, the section was adjusted to ensure that it was clear that the transferor is liable to amounts, whether or not the Minister has made an assessment. ${ }^{36}$

\section{A Glimpse at the Indebted Family}

With that background in place, I turn to the chief concern of this paper, which is determining what we can learn from the tax stories that arise when the Canadian dream of home ownership comes into conflict with our collective aspirations. In curating cases to review, I selected all of those decided after 2000 where income tax was at issue. ${ }^{37}$ Cases that were simply about the value of the property transferred, or that included a discussion of section 160 as only a subsidiary issue to the main concern of the case, were excluded. Those conditions reduced the number of cases to twenty-seven individuals who were transferred ownership of their family residence from a non-arm's length person at a time when the transferor had an income tax liability. ${ }^{38}$

What follows next is a selection of five stories, chosen randomly from the twenty-seven. On some level, it might seem unusual to simply work through the facts of these cases, as I have done in the part to follow, organized by alphabetical order of the last name. The purpose of reviewing the cases in this manner is to let at least a few of the stories of the people who have become legal subjects caught between our public and private aspirations stand as uninterrupted as possible.

\subsection{Richard Beaudin (son of Eula Lainé Beaudin and Rodolphe Beaudin) (2004) ${ }^{39}$}

Rodolphe and Eula Lainé Beaudin purchased a residence in Gallix, Quebec, in 1990, with the intention of using it as a cottage. Four years later, they moved into the home permanently. While initially holding the property in joint tenancy, Rodolphe transferred his interest to his wife in 1995 for no consideration. Rodolphe suffered from diabetes and heart problems; Eula suffered from high blood pressure.

2013, c 34, s 141.

2013, c 34, s 313 .

In other words, I excluded the cases that focused only on a GST assessment, for example.

Apa $v$ R, 2004 TCC 212, 2 CTC 2776; Beaudin v R, 2004 TCC 469, [2006] 5 CTC 2001 [Beaudin]; Biderman $v$ R, 2000 DTC 6149, 2 CTC 35 (FCA) [Biderman], aff'g (1998) 98 DTC 2188, 4 CTC 2144 (TCC); Bourget, supra note 1; Burns v R, 2006 TCC 309, 5 CTC 2392 [Burns]; Cohen v Canada, 2008 TCC 550, 2 CTC 2420; Darte v R, 2008 TCC 66, 5 CTC 2178 [Darte]; De Sanctis-Pedro v Canada, 2010 TCC 118, 4 CTC 2020 [De Sanctis-Pedro]; Dubois v R, 2003 TCC 16, 2003 DTC 527; Fallis $v$ R, [2002] 1 CTC 2661, 2002 DTC 1242 (TCC); Goldhawk, supra note 20; Leblanc $v$ R, 2008 TCC 242, [2009] 1 CTC 2308 [Leblanc]; Leclair $v$ Canada, 2011 TCC 323, 2011 DTC 1328; Madsen v Canada, 2006 FCA 47, 3 CTC 181 aff'g 2004 TCC 511, 4 CTC 3058 [Madsen]; Margetts v R, 2009 TCC 526, 2009 DTC 1347 [Margetts]; Provost v Canada, 2009 TCC 585, 2 CTC 2422 [Provost]; Quinton v R, [2000] 3 CTC 2310, 2000 DTC 2137 (TCC); Richard v R, 2003 TCC 790; 2005 DTC 953; Romar v Canada, 2013 FCA 10, 233 ACWS (3d) 766 aff'g 2012 TCC 104, 233 ACWS (3d) 766; Rose $v$ R, 2007 TCC 657, 3 CTC 2064 rev'd 2009 FCA 93, 3 CTC 236; Simone v R, 2005 TCC 231, 2005 DTC 537; Splinter v Canada, [2001] 3 CTC 2553, 2001 CarswellNat 1448 [Splinter]; St-Fort v Canada, 2009 FCA 188, 2010 DTC 4008 aff'g 2008 TCC 23, 2008 DTC 4604 [St-Fort]; Tétrault v R, 2004 TCC 332, 4 CTC 2234; Truong v Canada, 2011 TCC 380, [2012] 1 CTC 2075 [Truong]; Viau v Canada, 2011 TCC 193, 2011 DTC 1271; Warren v Canada, 2008 TCC 674, [2009] 2 CTC 2078.

Beaudin, supra note 38. 
Their health problems and excessive debt made it difficult for them to maintain their residence. Among their debts, Rodolphe owed approximately $\$ 335,000$ in outstanding taxes. At some point, Rodolphe declared bankruptcy. In 2000, their son, Richard, purchased the family cottage from them for $\$ 30,000$ (at a time when the cottage was valued at approximately $\$ 60,000$ ) in an attempt to assist them with their debts and to help them remain living in the cottage. Richard had to borrow money to pay the $\$ 30,000$. Richard made a verbal agreement with his parents that would allow them to remain in the house rent-free, paying only heating costs and minor maintenance. Richard paid most of the maintenance costs, as well as insurance and property taxes owing on the property. Rodolphe passed away in $2003 .{ }^{40}$

\subsection{Joanna Burns (common-law spouse of Glen McCarthy) (2006) ${ }^{41}$}

Joanna Burns and Glen McCarthy were common-law spouses who cohabited for twenty years, beginning in 1982. They purchased homes together in Brampton, Ontario, and later Caledon, Ontario. The house in Caledon was registered in Glen's name, the house in Brampton may have been as well. All expenses were paid from a joint bank account. Glen purchased a property in New Brunswick in 1987 with money from their savings. Two years later, in 1989, the couple sold their house in Caledon and built a house on the New Brunswick property with some of the proceeds from the sale. Glen retired and Joanna left her job. In 1992, they purchased and renovated a seasonal diner. Glen kept the books for the diner and Joanna ran it, largely without taking a salary (although she reported a salary in her tax returns). Joanna spent the winter months in Florida and she collected unemployment insurance benefits during that period (even though she was supposed to be residing in Canada while collecting them). Joanna filed her tax returns as single, enabling her to claim the goods and services tax credit (because she did not report Glen's income). They sold the diner in 1997. Glen purchased a truck and transferred it into Joanna's name because he was unable to get insurance for it himself. He also transferred the New Brunswick property to her name (valued at \$71,200), along with some timberland (valued at \$2,200), and continued to live in the house. He wanted to purchase another property in her name in 2000, but she refused. Glen had an accident in the truck, he was injured, and the truck was a write-off. In 2002, they separated. In 2004, Glen brought an action against Joanna claiming that he was the beneficial owner of the two properties (the motor vehicle and the New Brunswick house). She counterclaimed for an accounting of the properties and assets disposed of during their cohabitation. Later in 2004, Glen made an assignment in bankruptcy. By that time his debt with the Canada Revenue Agency, which had been mounting since 1992 , had reached almost $\$ 160,000 .^{42}$

40 The court found no evidence of an agreement for additional consideration to flow from the Beaudins to their son; hence, the son was liable for his parents' tax debt to the extent of the difference between the fair market value of the cottage and the consideration he paid for it. The court did, however, attribute some value to Richard's undertaking to pay some of the costs to maintain the home.

41 Burns, supra note 38.

42 The court held that Joanna Burns was liable for the tax debt of Glen McCarthy to the extent of the fair market value of the transferred properties. 


\subsection{Réjeanne Leblanc (spouse of André L'Écuyer) (2008) ${ }^{43}$}

Réjeanne Leblanc and André L'Écuyer married in 1993. Each had been married before. André had two children from a former relationship; Réjeanne had one. The couple kept family finances separate-keeping separate bank accounts with specific obligations and responsibilities. André paid the cable bill because Réjeanne felt that it was an unnecessary expense. The couple had three more children. Réjeanne worked at a financial institution and was very careful with her finances; she was able to save about $\$ 100,000$ over the years and she always paid bills as soon as she received them. She also paid all of the various household expenses, except the mortgage payment. Their division of financial responsibilities suited their personalities: Réjeanne managed multiple expenses (the clothing, food, school costs, telephone charges, health bills, and so on) and André only had to manage a few (the mortgage, the cable, and the hydro). In 1998 and 1999, André built up a tax debt of over \$26,000. Réjeanne and André lived in a home in Alma, Quebec, that was originally owned by André. Réjeanne made a $\$ 60,000$ loan to André for use in his business in 1999. The couple agreed that André would transfer the residence into Réjeanne's name to avoid any trouble with the potential repayment of the loan and in return she would expunge his debt to her. André continued to make mortgage payments to the bank after the transfer to avoid disturbing the way that family expenses were managed. The value of the home at the time of the transfer was $\$ 104,000$ with an outstanding mortgage of $\$ 35,412 .{ }^{44}$

\subsection{Christopher Michael Margetts (son of Bruce Margetts) (2009)}

In the 1980s, Ronald Margetts purchased a vacant piece of land in Halfmoon Bay, British Columbia. Starting a family recreational legacy project, he moved a house on to the land and made various improvements to it over time. When Ronald died in 1989, his wife, Mabel, inherited the property. The mortgage payments were too high for Mabel to maintain, and so she agreed with her children that two of them-Bruce and Leigh-would pay half of the mortgage and maintenance payments each. Mabel and Ronald's third child, Catherine, was unable to financially contribute. Simultaneously, Mabel agreed to sell the property to her three children. Mabel imposed conditions on the sale: that the three children would provide Mabel with a demand promissory note for the purchase price; that Mabel was given use of the property during her lifetime (in exchange for the payment of property taxes and utilities); that the three children would contribute equally to the upkeep of the property; and that, subject to Mabel's occupancy rights, they would have equal use of the property. Bruce was the sole director of two companies that went bankrupt in 2004. Bruce had an outstanding tax liability of over $\$ 185,000$. Mabel became concerned about Bruce's ability to financially keep up with his part of the transfer bargain. She wrote him

43 Leblanc, supra note 38.

44 The court held that Réjeanne provided sufficient consideration for the transfer of the house, and was therefore not liable for Andrés tax liability.

$45 \quad$ Margetts, supra note 38. 
a letter: "Due to your circumstances, I do not believe that you can live up to your obligations per the agreement between Ronald \& Mabel Margetts. I would like the situation dealt with." She signed the letter, Mabel Margetts. At a family gathering, Mabel provided Bruce with directions to transfer his interest in the property to her in satisfaction of his outstanding promissory note obligation. Instead of transferring his interest back to Mabel, in 2004 Bruce executed an agreement whereby he transferred his interest in the property, worth approximately $\$ 150,000$, to his son, Christopher Margetts. The mortgage at the time of the transfer exceeded $\$ 285,000{ }^{46}$

\subsection{Lieu Truong (spouse of Phat Le) $(2011)^{47}$}

Lieu Truong had a diploma in chemical technology and was working and living in Edmonton when she met Phat Le in 1997. She married him in June 2003 and moved to Vancouver in 2004 to be with him. Lieu had been loaning Phat money since 1998. She believed that he had financial difficulties as a result of a previous divorce. She did not keep good records of the loan amounts, but, as documented in a letter witnessed by a friend of Phat, Chinh Tran, they were in the range of $\$ 60,000$. Lieu testified that cash loans without documentation are common in Vietnamese culture. Lieu was able to make significant contributions to Phat because she was living with her brother in Edmonton and incurring few living expenses at the time. In 2005, Lieu began looking for a property in Vancouver. Her first offer was made using her name alone. When that offer was unsuccessful, she added Phat's name to the offer. Ultimately, Lieu and Phat jointly purchased a condominium in Coquitlam, British Columbia, for $\$ 210,477$ with a mortgage of $\$ 197,600$. Lieu paid the $\$ 10,000$ down payment and the transaction costs. She also paid the costs of maintaining the property including utilities, strata fees, painting, and re-flooring expenses. Phat paid the regular monthly mortgage payments as a way of returning some of the funds he had borrowed from Lieu. In 2006, Phat became ill. He signed a transfer agreement for ownership of the condominium, transferring his interest to Lieu for $\$ 1$. At the time of the transfer, Phat owed approximately $\$ 800,000$ in unpaid taxes. At the time of the transfer the fair market value of the property was $\$ 270,000$ and there was a mortgage of $\$ 196,117$. In 2008 , Phat declared bankruptcy. ${ }^{48}$

What can be gleaned from this archival look into tax cases? My claim is that reading these cases differently, with a focus only on their facts and not on the law or outcome, can teach us about who we are and about the public policy dilemmas of our times. Additionally, unlike work by other scholars that explores a particular case in its social or legal context, in this project, I am interested in what can be learned by looking at a cluster of cases with related facts. The effort is to pull together the people who find themselves in related real-life circumstances and to learn more about how they got there and what happens to them.

\footnotetext{
46 The court held that Christopher was jointly and severally liable for Bruce's tax obligations up to the value of the transferred property.

$47 \quad$ Truong, supra note 38.

48 The court held that Lieu was liable under section 160.
} 
First, and perhaps most obviously, section 160 leaves the consequences of private over-extension primarily on women and occasionally on children and parents. ${ }^{49}$ The transferee was the woman-spouse in twenty-one of the twenty-seven decisions. In no case did a woman incur a tax debt and transfer the family home to her (male) spouse. Perhaps, even though many women own businesses, ${ }^{50}$ they are less likely to engage in avoidance strategies to defeat either creditors or the Canada Revenue Agency. ${ }^{51}$ Perhaps if women get caught in the tax net, their male partners, then subject to section 160, are more likely to just pay the tax. Or perhaps, as the next observation suggests, women do not generally own the family home.

Second, the cases tell us something about how heterosexual couples own property. Even where the male partner in the relationship participates in business activities, which might suggest that creditor proofing by allocating legal ownership of the family assets to the female spouse is advisable, at least some couples fail to take this relatively simple step. Why? Perhaps because our conceptions of ownership make it difficult for some men to leave legal power over the family assets in the hands of women with whom they have intimate relationships. Perhaps it is a residual practice borne of centuries of property law doctrines that precluded women from owning property. ${ }^{52}$ Maybe it is because at least some men are unrealistically optimistic about risk, ${ }^{53}$ perhaps including the likelihood that their businesses will be successful, and so do not turn their mind to the allocation of legal ownership of assets at the outset or, even more surprising, when the business starts to falter but before the tax liability crystalizes.

There are surprisingly few cases where the transfer of the home moved vertically in a family instead of horizontally. One might expect that for a couple in financial

49 To that end, this piece contributes to the literature on "sexually transmitted debt." See e.g. Belinda Fehlberg, "Money and Marriage: Sexually Transmitted Debt in England," International Journal of Law, Policy and the Family 11:3 (1997): 320.

50 Although in many businesses women have some ownership (Canada, Foreign Affairs, Trade and Development Canada, "Facts and Figures on Canadian Women Entrepreneurs" The Canadian Trade Commissioner Service (Ottawa)), fewer businesses have a majority ownership stake held by women (Canada, Industry Canada, Majority Female-Owned Small and Medium-Sized Enterprises, Special Edition: Key Small Business Statistics (Ottawa: Small Business Branch, May 2015).

51 See e.g. Barbara Katslunger, "Sex Differences in Tax Compliance: Differentiating Between Demographic Sex, Gender-role Orientation, and Prenatal Masculinization (2D:4D)," Journal of Economic Psychology 31:4 (2010): 542; Janne Chung and Viswanath Umashanker Trivedi, "The Effect of Friendly Persuasion and Gender on Tax Compliance Behaviour," Journal of Business Ethics 47 (2003): 133.

52 See e.g. Maeve E. Doggett, Marriage, Wife-Beating and the Law in Victorian England (Columbia, SC: University of South Carolina Press, 1993); Constance Backhouse, "Married Women's Property Law in Nineteenth-Century Canada," Law and History Review 6:2 (1988): 211; Karen Pearlston, "Coverture and Private Separation: Britain and Ontario in Comparative Perspective" (2012) [unpublished, archived at University of New Brunswick, Faculty of Law]. Accessed http://papers. ssrn.com/sol3/papers.cfm?abstract_id=2240006 3 January 2016; Tim Stretton and Krista Kesserling, eds., Married Women and the Law: Coverture in England and the Common Law World (Montreal \& Kingston: McGill-Queen's University Press, 2013).

53 See e.g. James P. Byrnes, David C. Miller, and William D. Schafer, "Gender Differences in RiskTaking: A Meta-Analysis," Psychology Bulletin 125:3 (1999): 367; Sapienza et al., "Gender Differences in Financial Risk Aversion and Career Choices Are Affected by Testosterone," Proceedings of the National Academy of Science United States of America 106:39 (2009): 15268; Ling-Ling Chang, Yann-Ching Tsai, and Gin-Yuan Lee, "Gender Differences in Optimism: Evidence From Yahoo Kimo Taiwan's Business Polls Centre," Social Behaviour and Personality 38:1 (2010): 61; Philip Lemaster and JoNell Strough, "Beyond Mars and Venus: Understanding Gender Differences in Financial Risk Tolerance," Journal of Economic Psychology 42 (2014): 148. 
difficulties, the family might look to transfer the legal ownership of the assets to their children or their parents. However, it seems that spouses keep legal ownership of family assets between themselves. In only twenty percent of the cases was the transferee someone other than a spouse-for example, a child or sibling. Our culture of home ownership does not suggest that we see "family," even conventionally understood "nuclear family," as a viable part of a home ownership plan. Perhaps we do not share information about our financial woes with our children or parents.

Third, the cases show the real financial pressures under which some families live. Stories thick with facts and charts about Canadians' mounting debts have proliferated in newspapers. ${ }^{54}$ Sometimes those stories include vignettes of particular individuals, generally people living under the pressure of either student debt or mortgages. These tax stories reveal something slightly different: they reveal the family and relational costs of mounting debt. Imagine the lives of any of the women who find themselves responsible for the tax debts incurred by their husbands. They may be women who have paid their taxes, kept careful accounts of family expenditures on household items, cut coupons from newspapers, started savings accounts for their children's education, comparison shopped for the large ticket family purchases, and so on. In other words, they may have done everything "right" in their efforts to budget for their family's wellbeing and their own longterm financial stability. In the cases caught by section 160 , however, the dream has come crashing down. In many of the cases where section 160 is held to apply, the family will need to sell the family home (which is likely their only major investment asset, unless there are substantial pension savings) in order to satisfy the debt incurred by their husbands. In some cases, for example, for the Beaudins, ${ }^{55}$ Joanna Burns and Glen McCarthy, ${ }^{56}$ Diana De Sanctis-Pedro and Adamo De Sanctis, ${ }^{57}$ the Madsens, ${ }^{58}$ Christopher and Bruce Margetts, ${ }^{59}$ the Provosts, ${ }^{60}$ the Romars ${ }^{61}$, the Splinters, ${ }^{62}$ the St-Forts, ${ }^{63}$ Lieu Truong and Phat Le, ${ }^{64}$ the equity in the home is less than the tax debt outstanding. We can only imagine, but without too much trouble, the pressure that kind of discovery (that the home will need to be sold) places on an intimate or parental relationship. A review of the dates of the transfers against the dates of the court decisions reveals that often these disputes take a decade or more to resolve. The ongoing uncertainty about the outcome of these disputes, which is about the uncertain tax liability primarily of women who are

54 For details of the changes in the debts of Canadians see Canada, Statistics Canada, Raj Chawla and Sharanjit Uppal, Household debt in Canada (Ottawa: March 2012) (concluding that mortgage debt (and consumer debt) have increased significantly in recent years); Canada, Statistics Canada, Sharanjit Uppal and Sébastien LaRochelle-Côté, Changes in debt and assets of Canadian families, 1999-2012 (Ottawa: April 2015). (See especially Table A.1 at 11, which shows the increases in average debt due to mortgages between 1999 and 2012 by demographic group.) Beaudin, supra note 38.

Burns, supra note 38.

De Sanctis-Pedro, supra note 38.

Madsen, supra note 38.

Margetts, supra note 38.

Provost, supra note 38.

Romar, supra note 38.

Splinter, supra note 38.

St-Fort, supra note 38.

Truong, supra note 38. 
or were spouses of men who owe taxes, must be gruelling. In five of the twenty-one cases that feature spouses, the facts record that the spouses have separated following the time when the tax debt was incurred.

In a surprising number of cases, surprising because it is not relevant to the determination of whether section 160 should apply, the relationship between the intimate partners is described in a way that reveals allegations of domestic abuse of various sorts. For example, Gillian Darte testified that Danny MacAdam, her common-law partner, was violent and an alcoholic ${ }^{65}$ and Linda Jean Provost testified that Gary Provost was violent and that she did as he asked to avoid reprisal. ${ }^{66}$

Fourth, the cases reveal the lengths to which some people (in these cases, the men who incur the tax debts) will go to avoid paying their taxes or to comply with other regulatory regimes. Most of the cases feature men in business. That is predictable because employees have fewer opportunities to deduct questionable expenses, claim inappropriate losses, or shelter income. In some cases, the houses purchased are expensive and the tax debts incurred are substantial. There are also some connections between the people who find themselves behind on their public obligations not only in the realm of tax, but also in other aspects of their lives. For example, in some of the cases, the parties have had other financially-rooted challenges with legal regulation and find themselves disbarred from their professional practices (Michael Biderman was disbarred for the improper use of trust funds), ${ }^{67}$ engaged in illegal activities in terms of the collection of public benefits (Joanna Burns collected unemployment insurance benefits although she was residing in Florida and did not declare Glen as her common-law spouse so that she could obtain the goods and services tax credit), ${ }^{68}$ or imprisoned for tax offences (Danny MacAdam) ${ }^{69}$ or other offences (Gary Provost was incarcerated for drug offences). ${ }^{70}$

Fifth, the cases show how financially messy our lives are. Almost all of the cases feature men (or families) who operate small businesses. Their personal and professional financial lives are intimately integrated. When financial pressures erupt, it is almost impossible to isolate their personal assets from their business assets.

Sixth, the cases provide a window into the lives of a diverse group of Canadians, with the caveat that to be subject to a section 160 assessment, the transferor has to have had sufficient income to have purchased an asset (in these cases, a home). The parties to the cases come from across the country-from London, Ontario, to Alma, Quebec, to Howe Island, British Columbia. To the extent that one can infer anything from the names of the parties, they represent a broad range of ethnic and racial communities. Despite choosing cases in the post-modernization era, ${ }^{71}$ where same sex couples might find themselves the subject of tax regulation, none of the cases feature same-sex couples.

\footnotetext{
Darte, supra note 38 at para 6.

Provost, supra note 38 at para 7.

Biderman, supra note 38 at para 24.

Burns, supra note 38 at para 15.

Darte, supra note 38 at para 8.

Provost, supra note 38 at para 7.
}

In 2000, the federal government passed the Modernization of Benefits and Obligations Act, SC 2000, c 12. This Act enacted changes to sixty-eight statutes to extend benefits and obligations that were available to married spouses to common law relationships, including same-sex relationships. 
The facts of these cases also reveal something about public policy tensions that should perhaps be addressed through changes to social, political, and economic policy. Perhaps surprisingly, none of these general policy issues-the gendered effect of section 160's reach, the nature of the full picture of people's financial reality at the point where section 160 often applies, and the complexity of our human and financial arrangements-were issues that were discussed in the parliamentary sessions during section 160's enactment and amendment. In some ways, that underscores the object of this research work, which is to see how cases might be used to help us understand something about the social, economic, and political contexts we find ourselves in when our lives intersect with law.

There are, in brief, things to learn from these cases. Most importantly, they provide a sense of our limited understanding of financial and legal issues around the legal transfer of a home within the family. Section 160 is a relatively straightforward section and it should be the rare person who finds themselves caught: still, a surprising number of cases reach litigation on it. Second, the cases confirm that men continue to own family property. This suggests the need for greater education, for women and men, and presumably those who advise them on elements of their financial planning, like bankers, about the consequences of legal ownership and for continued education to enhance equality within intimate partnerships. Third, the cases affirm research that suggests that people who operate small businesses labour under overconfidence biases: even in the face of evidence that businesses are failing, people fail to take appropriate steps to protect their personal assets. The cases arising under section 160 make plain that there is more to do to educate people about the consequences of their financial engagements.

The objective of this paper was never to offer definitive conclusions about the lives of people who live at the nexus of our public aspirations and our private wants. Instead, the paper sought to challenge our understanding of what is important about law: that law (in the form of cases) might be used as an archaeological site, and the facts that it renders visible might be seen as a valuable form of knowledge. Additionally, I sought to lay bare something, even if only something modest, about the lives people live when their home ownership aspirations exceed their ability to satisfy their tax obligations and to draw some tentative conclusions about what non-law public policy responses might be appropriate if we look backward from tax cases.

Kim Brooks

Professor,

Schulich School of Law,

Dalhousie University

Halifax, Nova Scotia, Canada

and Senior Research Fellow,

Taxation Law and Policy Research Institute,

Monash University

Clayton, Victoria, Australia

kim.brooks@dal.ca 